Volume 14. Nomor 1. June 2019 Page 1-12
Pandecta
http://journal.unnes.ac.id/nju/index.php/pandecta

\title{
Pengaruh dari Kedaulatan Negara terhadap Pelaksanaan Mekanisme Kerjasama ASEAN dalam Pemberantasan Terorisme
}

\author{
Budi Hermawan Bangun
}

Fakultas Hukum Universitas Tanjungpura, Pontianak, Kalimantan Barat, Indonesia

DOI: http://dx.doi.org/10.15294/pandecta.v14i1.17777

\begin{tabular}{|c|c|}
\hline Article info & Abstrak \\
\hline $\begin{array}{l}\text { Article History: } \\
\text { Received : January } 2019 \\
\text { Accepted: June } 2019 \\
\text { Published: June } 2019\end{array}$ & \multirow{2}{*}{$\begin{array}{l}\text { Tulisan ini menganalisis kedaulatan negara dan pengaruhnya terhadap pelaksanaan } \\
\text { mekanisme kerjasama ASEAN dalam pemberantasan terorisme. Hambatan dalam } \\
\text { upaya penanganan masalah terorisme justru ditimbulkan karena prinsip kedaula- } \\
\text { tan negara yang dipertahankan secara kuat oleh negara-negara anggota ASEAN. } \\
\text { Kesulitan dalam mencapai konsensus yang merupakan mekanisme pengambilan } \\
\text { keputusan ASEAN telah mendorong sementara negara anggota untuk mengaktifkan } \\
\text { opsi-opsi yang berkerangka bilateral atau trilateral, yang kurang produktif terhadap } \\
\text { upaya pengembangan wawasan regional. Hal inilah yang kemudian menjadikan im- } \\
\text { plementasi kesepakatan di ASEAN menjadi lambat dan tidak efektif. }\end{array}$} \\
\hline $\begin{array}{l}\text { Keywords: } \\
\text { ASEAN, state sovereignty, } \\
\text { terorism }\end{array}$ & \\
\hline
\end{tabular}

\begin{abstract}
This paper analyzes the sovereignty of the state and its influence on the implementation of ASEAN cooperation mechanisms in combating terrorism. Obstacles in the effort to deal with the problem of terrorism actually arise because of the principle of state sovereignty which is strongly maintained by ASEAN member countries. Difficulties in reaching consensus which is the ASEAN decision-making mechanism have encouraged temporary member states to activate bilateral or trilateral options, which are less productive towards efforts to develop regional insights. This is what then makes the implementation of the agreement in ASEAN to be slow and uneffective.
\end{abstract}




\section{Pendahuluan}

Salah satu wujud komunitas ASEAN di bidang politik keamanan adalah pemberantasan terorisme. Dewasa ini terorisme telah menjadi ancaman paling serius bagi kemanusiaan dan peradaban serta membawa dampak sangat besar di segala aspek kehidupan berbangsa dan bernegara. Pada tingkat regional, Asia Tenggara merupakan kawasan yang menghadapi tantangan cukup berat dalam bidang keamanan (Sudirman \& Sari 2017: 23; Tjarsono, 2012: 2). Masalah terorisme merupakan masalah yang banyak dihadapi oleh negara-negara Asia Tenggara. Banyaknya peristiwa terorisme yang terjadi di Asia Tenggara telah mengakibatkan ASEAN dituntut untuk berperan lebih besar dalam menyelesaikan masalah ini.

Berbagai masalah terorisme menimpa ASEAN, seperti pemboman di Bali, Oktober 2002 dan Hotel JW Marriot Jakarta Agustus 2003 dan sejumlah aksi pengeboman di Filipina yang diduga terkait dengan jaringan Jamaah Islamiah (JI) di Singapura, Malaysia dan Thailand. Baru-baru ini, kasus Islamic State of Iraq and Syria (ISIS) di Irak-Suriah diyakini mampu membangkitkan dan menginspirasi makar maupun aksi teror di regional Asia Tenggara. Pihak berwenang di setiap negara ASEAN harus mulai menyadari potensi tumbuhnya bibit-bibit radikalisme Islam di area masing-masing, sebab kali ini, ISIS sangat masif, kreatif, serta menarik minat pemuda melakukan propaganda dibandingkan JI ataupun Al-Qaeda pada dekade yang lalu.

Hal ini semakin menguatkan ASEAN untuk bertindak lebih aktif. Para elite pemerintahan ASEAN menyadari bahwa sudah saatnya ASEAN mempunyai instrumen yang efektif untuk memerangi terorisme. ASEAN mempunyai kepentingan bersama untuk bekerjasama dalam memerangi kejahatan lintas negara, utamanya terorisme. Hal ini karena pada kenyataannya kejahatan lintas negara termasuk terorisme telah beroperasi secara transnasional.

Pada tanggal 13 Januari 2007 di Cebu, Filipina, para pemimpin negara-negara ASEAN telah menyepakati ASEAN Convention on Counter Terrorism (ACCT). ACCT kini telah diratifikasi oleh semua sepuluh negara anggota ASEAN. Ditandatangani oleh pemimpin ASEAN pada tahun 2007, ACCT adalah prestasi yang signifikan dari upaya kontra-terorisme ASEAN karena berfungsi sebagai kerangka kerja untuk melawan, mencegah dan menekan terorisme dan memperdalam kerjasama kontraterorisme., serta untuk meningkatkan peran strategis di kawasan ini dalam strategi global anti-terorisme. ACCT mulai berlaku pada tanggal 27 Mei 2011dan saat ini telah diratifikasi oleh seluruh negara anggota ASEAN.

Meskipun ASEAN telah memiliki ACCT, namun seperti menghadapi isu-isu lainnya, respon negara-negara ASEAN dalam menghadapi dan memberantas terorisme sesungguhnya masih sangat bertumpu pada inisiatif masing-masing negara anggota. Hal ini dapat dipahami, sebagaimana kritik dari beberapa analis, kelahiran ASEAN tidak dilatari oleh fondasi institusional yang kokoh (tidak seperti Uni Eropa, misalnya), oleh karenanya stabilitas bukan hal yang dapat dijelaskan secara objektif apakah mampu bertahan lama atau tidak (Kivimäki, 2012: 404). ASEAN juga dikritik punya kelemahan karena sebagai organisasi internasional memiliki sumber daya yang minim yang secara kelembagaan tidak efisien (Jasudasen, 2019).

Keberadaan Treaty of Amity and Cooperation (TAC) yang telah disepakati ASDAN sejak tanggal 24 Februari 1976, pada satu sisi merupakan keuntungan sebagai jaminan stabilitas keamanan di kawasan Asia Tenggara namun acapkali juga TAC yang melahirkan "ASEAN Way" menjadi hambatan pada efektivitas penyelesaian masalah-masalah yang dihadapi ASEAN, termasuk juga masalah yang berkaitan dengan pemberantasan terorisme. Sendi-sendi normatif yang terkandung dalam "ASEAN Way" antara lain adalah prinsip untuk melakukan kerjasama secara damai, harmoni, saling menghormati kedaulatan wilayah (national sovereignty) masingmasing, tidak mencampuri urusan domestik negara anggota, egaliter, menerapkan kaídah konsensus dalam menghasilkan berbagai keputusan, tenggang rasa dan non konfrontatif, saling membantu, melakukan diplomasi se- 
cara diam-diam tidak melalui media, menjunjung tinggi solidaritas, non legalistik dan pragmatis (Susastro, 1995).

Karena itu, implementasi mekanisme penyelesaian masalah terorisme di ASEAN sangat terkait dengan tinggi rendahnya kepekaan negara-negara ASEAN terhadap masalah kedaulatannya. Semakin peka negara-negara terhadap masalah kedaulatannya maka semakin sulit untuk mengembangkan sikap "terpadu" dalam menyelesaikan masalahmasalah keamanan bersama dengan kata lain ketika masing-masing negara anggota mengedepankan kepentingan nasional, maka akan semakin sulit diperoleh kesamaan pandangan terkait dengan pelaksanaan mekanisme penanggulangan terorisme di kawasan Asia Tenggara. Berkaitan dengan hal tersebut, tulisan ini, hendak membahas mengenai kaitan atau pengaruh antara kedaulatan negara dengan pelaksanaan mekanisme kerjasama ASEAN dalam penanggulangan terorisme di Asia Tenggara.

\section{Metode Penelitian}

Sesuai dengan substansi permasalahan hukum yang hendak dikaji dalam penelitian ini, maka penelitian ini dirancang sebagai suatu penelitian yang bersifat normatif (dogmatik), yaitu suatu penelitian yang terutama mengkaji ketentuan hukum positif, maupun asas-asas hukum, dengan melakukan penjelasan secara sistematis ketentuan hukum dalam sebuah kategori hukum tertentu, menganalisis hubungan antara ketentuan hukum, menjelaskan aplikasi ketentuan hukum dalam lapangan bekerjanya hukum dan memprediksi pengembangan ke depan (Hutchinson, 2002: 9). Untuk mengkaji permasalahan yang ada maka penelitian ini menggunakan beberapa pendekatan, yakni: pendekatan peraturan perundang-undangan (statute approach), pendekatan komparatif (comparative approach), dan pendekatan konseptual (conseptual approach). Data yang digunakan dalam penelitian ini tertuju pada data sekunder dan diperoleh melalui penelitian kepustakaan. Data yang didapatkan kemudian selanjutnya dianalisis secara kualitatif untuk menarik kesimpulan yang menjawab masalah yang dibahas sekaligus memberikan preskripsi berdasarkan argumentasi yang telah dibangun di dalam kesimpulan.

\section{Hasil dan Pembahasan}

\section{Kedaulatan Negara dalam Perspektif Negara-Negara ASEAN}

Kedaulatan merupakan konsep yang terus berubah seiring dengan perkembangan zaman. Robert Jackson memprediksi, cepat atau lambat, kedaulatan negara akan tergantikan oleh tatanan politik dan otoritas legal lain. Menurut Jackson, kedaulatan negara akan berakhir ketika rakyat tidak lagi siap menerima doktrin bahwa setiap komunitas politik harus tunduk pada pemerintahan yang memiliki mandat di atas otoritas lain dalam negara dan independen dari semua pemerintahan asing (Jackson, 2007: 112-113).

Pendapat Jackson menjadi sangat relevan bila dihubungkan dengan kenyataan semakin signifikannya pengaruh fenomena globalisasi terhadap eksistensi kedaulatan dan wilayah negara. Dalam pandangan beberapa ahli, globalisasi dianggap telah menggeser makna kedaulatan yang sebelumnya terkonsentrasi pada negara dan kini berpindah ke komunitas global. Globalisasi juga meniadakan batas-batas wilayah yang dahulu tersekat-sekat dan kini berubah tanpa batas dan bahkan mereduksi peran negara di pentas dunia (Ohmae, 1995).

Fenomena globalisasi ditandai dengan pertumbuhan berbagai organisasi internasional dan meningkatnya intensitas hubungan politik yang melintasi batas negara-bangsa (nation-states). Hal ini menyebabkan keputusan dan tindakan politik pada satu bagian dunia dapat mempengaruhi bagian dunia lainnya secara cepat. Sebagai implikasinya, perkembangan pada tingkat global memperoleh konsekuensi logis dari fenomena itu berupa munculnya kompleksitas dan koneksi antar masyarakat serta unsur-unsur sosial, budaya, ekonomi maupun politik secara masif. Negara yang awalnya menjadi aktor paling berkuasa dalam bingkai hubungan internasional, kini harus berbagi wilayah peran dan kekuasaannya dengan aktor-aktor lainnya seperti, perusahaan multinasional (multi na- 
tional corporations), gerakan masyarakat sipil global (global civil society movements), dan kelompok penekan internasional (international pressure group) (Held dan McGrew, 1999: 49-50).

Sejalan dengan itu, Holli Thomas menyatakan bahwa proses globalisasi telah memunculkan aktor-aktor baru yang turut mempengaruhi perkembangan dunia, seperti komunitas internasional dan masyarakat sipil global. Negara tidak lagi menjadi pemain kunci sehingga tata kelola dunia juga menjadi tanggung jawab aktor non-negara. Akibatnya, kedaulatan negara tidak semutlak era ketika Perjanjian Westphalia (1648) melahirkan sistem negara modern yang mempertegas posisi kedaulatan dalam negara. Karena itu, Thomas berpendapat bahwa dunia sedang bergerak menuju apa yang disebutnya sebagai "post-sovereign world", di mana legitimasi dan otoritas absolut tidak lagi bersandar pada aspek teritorial negara. Kedaulatan seharusnya dibagi dengan otoritas lokal, regional, dan global dan direinterpretasi sebagai kondisi ketika negara bertanggung jawab menjamin hak asasi manusia. Tanggung jawab itu melintasi batas-batas wilayah negara sehingga suatu negara harus peduli pada persoalanpersoalan kemanusiaan yang membelit warga negara lain (Thomas, 2004: 3-5).

Kepedulian terhadap persoalan-persoalan kemanusiaan inilah yang menghasilkan cosmopolitan sovereignty (Thomas, 2004: 22), yakni sebuah kedaulatan yang menjamin setiap orang dilindungi oleh jaringan institusi yang melampaui mandat pemerintahan yang mempunyai legitimasi. Dalam cosmopolitan sovereignty, masyarakat internasional memiliki mandat untuk mengintervensi persoalanpersoalan domestik negara demi kepentingan kemanusiaan (Thomas, 2004: 24-25).

Bagi Stephen Krasner, eksistensi dan kedaulatan negara-bangsa sesungguhnya tidak berubah secara fundamental akibat globalisasi namun hanyalah sebagai tantangan saja. Krasner (1999: 34) mengatakan:

"....sovereignty is not being fundamentally transformed by globalization. Globalization has challenged the effectiveness of state control; although it is not evident that contemporary challenges are qualitatively different from those that existed in the past. Globalization has not, however, qualitatively altered state authority which has always been problematic and could never be taken for granted."

Dalam kaitannya dengan semakin berkembangnya hukum internasional di era globalisasi, lagi-lagi Krasner menegaskan bahwa globalisasi dan hukum internasional tidak melemahkan kedaulatan negara-bangsa melainkan justru menegaskan bahwa "international legal sovereignty" lebih penting dari masa-masa sebelumnya. Hal ini disebabkan karena hukum internasional tidak mungkin dibuat tanpa adanya pengakuan (recognition) dari negara-bangsa karena prinsip hukum internasional sama dengan hukum nasional yakni "mutual recognition". Bagi Krasner (1999: 48-49):

"... globalization has enhanced the incentive to reach agreements in some areas because unilateral control is more difficult. Viewed from the perspective of international law, however, these agreements enhance rather than undermine sovereignty. Indeed, the agreements would be impossible in the first place if states did not mutually recognize their capacity to enter into them."

Alih-alih melemahkan kedaulatan negara, globalisasi bahkan telah mendorong suatu "incentive" bagi upaya melahirkan persetujuan-persetujuan internasional. Dengan demikian globalisasi bukannya melemahkan (undermine) kedaulatan negara melainkan justru memperkuatnya (enhance it).

Ketidaksetujuan terhadap melemahnya eksitensi dan kapasitas kedaulatan negara dalam era globalisasi juga diutarakan oleh Martin Wolf. Wolf memulai argumentasinya dengan menyatakan bahwa dalam mengikuti globalisasi, yang memberi keputusan akan keikutsertaan tersebut sendiri ialah negara. Dapat dilihat bahwa di samping negaranegara yang memutuskan untuk mengikuti arus globalisasi, terdapat negara yang memutuskan untuk tidak turut dalam hiruk pikuk globalisasi, seperti Korea Utara (Wolf, 2005: 205).

Khusus dalam konteks kewilayahan dan populasi, negara masih memegang peranan yang signifikan. Sebagai contoh ialah ba- 
gaimana negara mengatur migrasi dan mobilitas warga negaranya dan warga negara asing yang akan masuk dalam negaranya. Sebuah proteksi yang kuat harus diupayakan negara untuk menjamin kemakmuran rakyat.

Negara harus menjamin keamanan dan kemakmuran warga negaranya dengan melakukan proteksi dan mengeluarkan kebijakan yang bersifat proteksionis, guna menjawab kewajiban untuk menjaga otoritas atas diri warga negara yang telah diberikan kepada negara dalam proses kontrak sosial, dengan jaminan keamanan dan kemakmuran.

Prospek otoritas dan kedaulatan negara akan tetap memainkan peranan substansial dalam globalisasi. Negara dengan otoritas yang dimilikinya tetap berperan dalam menjamin kepentingan dan menyediakan identitas warga negaranya. Negara sebagai yurisdiksi wilayah juga merupakan landasan bagi tatanan global (Wolf, 2005: 276-277). Karena itu keberadaan negara dan kedaulatan dalam globalisasi masih tetap memiliki tempat, terlebih berkaitan dengan pembuatan keputusan serta kebijakan suatu negara dalam menjawab tantangan globalisasi.

Dalam perspektif negara-negara di Asia Tenggara, kedaulatan negara merupakan sesuatu yang sangat penting terutama bila isuisu yang berkaitan dengan hal tersebut menyangkut hubungan dengan negara lainnya.

Dasar awal tujuan pembentukan ASEAN ini menekankan pada unsur kedaulatan masing-masing negara anggota. Penguatan kedaulatan secara mutual oleh masing-masing negara ASEAN berdasarkan pada: pertama, membangun interaksi kerjasama politik dan ekonomi antar sesama; kedua, dengan ASEAN maka pembangunan ekonomi antar negara akan semakin kuat; dan ketiga, dengan adanya kemanan internal maka ASEAN akan mengurangi kerentanan negara anggota terhadap kekuatan ekternal (Narine, 1999: 359). TAC yang telah ada sejak tahun 1976 telah melahirkan norma dasar bagi ASEAN yang salah satunya adalah prinsip tidak mencampuri urusan negara lain (non-interference). Selain itu, TAC juga telah melahirkan sebuah mekanisme yang khas dan kemudian dikenal sebagai "The ASEAN Way", yaitu cara-cara ASEAN dalam menanggapi dan menanggulangi permasalahan yang ada. Sendi-sendi normatif yang terkandung dalam "ASEAN Way" antara lain ádalah prinsip untuk melakukan kerjasama secara damai, harmoni, saling menghormati kedaulatan wilayah (national sovereignty) masing-masing, tidak mencampuri urusan domestik negara anggota, egaliter, menerapkan kaídah konsensus dalam menghasilkan berbagai keputusan, tenggang rasa dan non konfrontatif, saling membantu, melakukan diplomasi secara diam-diam tidak melalui media, menjunjung tinggi solidaritas, non legalistik dan pragmatis (Bangun, 2017).

Menurut Bambang Cipto (2007: 3132), prinsip non-interference merupakan salah satu fondasi terkuat yang menopang eksistensi ASEAN sebagai sebuah organisasi regional. Implementasi dari prinsip ini diwujudkan pada tindakan-tindakan berupa:

1. Berusaha untuk tidak memberikan penilaian kritis terhadap kebijakankebijakan domestik yang diambil oleh negara-negara anggota;

2. Mengingatkan negara-negara anggota lain yang dinilai melanggar prinsip tersebut;

3. Menentang pemberian perlindungan bagi kelompok oposisi dari suatu negara anggota lain;

4. Mendukung dan membantu negara anggota lain yang sedang menghadapi gerakan anti kemapanan.

Penghormatan atas kedaulatan negaranegara anggota semakin diperkuat oleh Piagam ASEAN (ASEAN Charter). Pasal 2 ayat (2 a) Piagam ASEAN menegaskan bahwa: "menghormati kemerdekaan, kedaulatan, kesetaraan, integritas wilayah, dan identitas nasional seluruh negara-negara anggota ASEAN", merupakan salah satu prinsip yang wajib dipatuhi. Sementara itu, Pasal 2 ayat 2 (e) dan (f) mempertegas pentingnya prinsip non-interference bagi negara-negara anggota ASEAN.

\section{ASEAN dan Pemberantasan Terorisme}

Perkembangan situasi global yang sangat pesat dalam beberapa dekade terakhir mengharuskan ASEAN harus mampu bereak- 
si menghadapi situasi global yang baru dan mengkonsolidasi diri untuk mewujudkan cita-cita regionalnya. Salah satu hal baru yang harus dihadapi oleh ASEAN adalah pemberantasan terorisme.

Terorisme internasional yang dianggap berkembang bersama di atas kejahatan lintas negara memperkuat kembali konsep ASEAN Way. Semua persetujuan untuk memberantas terorisme internasional di wilayah Asia Tenggara didasarkan atas pasal-pasal yang terpenting dalam TAC terutama Pasal 2 yang berisi prinsip: saling menghormati kedaulatan, non-interference dan peuyelesaian sengketa secara damai.Prinsip-prinsip penting dalam TAC tersebut kemudian menjadi pedoman dalam setiap pengambilan keputusan ASEAN melalui konsensus. Kalau konsensus tidak tercapai, termasuk dalam memerangi terorisme di tingkat ASEAN, di samping peraturan peraturan pemerintah pengganti undang-undang atau undang-undang anti terorisme masingmasing negara anggota, maka negara-negara anggota tertentu yang menganggap bahwa terorisme sudah sangat mengganggu, dan persetujuan ASEAN tidak memadai, membuat persetujuan sendiri untuk menghadapi kejahatan terorisme tersebut (Luhulima, 2003: 32).

Aturan permainan yang didasarkan pada TAC menegaskan suatu ciri fundamental regionalisme ASEAN. ASEAN tetap harus merupakan suatu bergantung pada kemauan politik setiap negara anggota untuk melepaskan komponen yang relevan dari kedaulatan mereka masing-masing untuk membangun suatu kehidupan Asia Tenggara yang terorganisasi. Karena itu level dan bobot kerjasama ASEAN banyak ditentukan oleh kepentingan nasional dari masing-masing negara anggota. Jadi, level dan bobot interaksi antar negara ASEAN hanya dapat meningkat apabila negara anggota dapat mengatasi persoalan tersebut, dalam arti mendudukan kepentingan nasional dan kedaulatan yang dimilikinya secara berdampingan dengan kepentingan kawasan. Di sinilah exercise ASEAN dalam perjalanannya ke depan.

Sejalan dengan hal di atas Philips Jusario Vermonte menyatakan bahwa kerja- sama ASEAN yang lebih kongkret, terutama sebagai mekanisme penyelesaian konflik regional, berjalan sangat lambat. Hal ini antara lain terjadi karena hakikat ASEAN yang dikenal sebagai organisasi yang lebih bersifat sovereignty enhancing daripada sovereignty reducing. Oleh karenanya itu, ASEAN harus mengkaji ulang dan melonggarkan prinsipprinsip kedaulatan yang selama ini dikedepankannya untuk mencapai kerjasama yang lebih substansial, misalnya mekanisme kontrol perbatasan atau patroli bersama antar negara-negara ASEAN (Vermonte, 2003: 67).

Perbedaan kepentingan nasional dan perspektif dalam pemberantasan terorisme dapat menghambat upaya penanganan masalah terorisme. Hal ini secara nyat dapat terlihat dengan tidak seragamnya pendekatan dan penanganan terhadap terorisme yang dilakukan oleh negara-negara anggota. Indonesia sebagai negara yang beberapa kali peristiwa terorisme sangatan mengandalkan ayang aparat keamanan (security apparatus) negara dan tersebar dalam banyak badan dan lembaga, seperti Badan Nasional Penanggulangan Teror (BNPT), badan intelejen, militer, kepolisian dan penegak hukum seperti Kejaksaan. Khusus di tubuh kepolisian, sebuah unit anti terror dibentuk dengan dukungan logistic dan kapabilitas yang besar, yaitu Detasemen Khusus 88 (Densus 88). Sementara itu, Malaysia dan Singapura hanya mengandalkan proses penegakan hukum secara tegas yang mereka memang miliki sejak lama ditambah dengan Internal Security Act (ISA. Thailand dan Filipina mengandalkan aparat intelejen dan militer, Negara-negara ASEAN lainnya seperti Vietnam, Kamboja, Brunei Darussalam dan Myanmar masinh menggunakan pendekatan hukum dan krimininal serta pembekuan asset terhadap tersangka terorisme dan sama sekali tidak melibatkan militer (Sudirman \& Sari 2017: 25-26).

Meskipun telah disepakati beberapa persetujuan terkait dengan penenggulangan terorisme, adanya perbedaan kepentingan dan perspektif telah mendorong sementara negara anggota untuk mengaktifkan opsiopsi yang berkerangka bilateral atau trilateral, sesuatu yang cenderung kurang produktif 
terhadap upaya pengembangan wawasan regional. Mekanisme konsensus menyebabkan dalam tingkat apapun penanganan masalah terorisme di ASEAN hanya akan bisa dilakukan apabila pihak-pihak yang bersangkutan menyetujui. Hal inilah yang kemudian menjadikan implementasi kesepakatan di ASEAN menjadi lambat dan bahkan tidak berjalan.

Peristiwa kejahatan transnasional terutama terorisme yang terjadi di kawasan Asia Tenggara telah memberikan pelajaran yang amat berharga pada ASEAN. Pertama, krisis tersebut telah menggarisbawahi dilema yang sangat sulit antara keinginan untuk tetap mempertahankan peran sentral negara di dalam kehidupan domestik dan internasional, serta di sisi lain adanya realitas semakin terkikisnya kedaulatan suatu negara sebagai akibat dari globalisasi.

Terorisme sebagai fenomena penggunaan kekerasan untuk mencapai tujuan politik tertentu sudah terjadi jauh sebelum peristiwa pemboman gedung World Trade Center (WTC), di New York pada 11 September 2001 atau lebih populer dengan istilah 9/11. Meskipun motivasi untuk melakukan aksi terorisme bisa berbeda-beda sepanjang sejarah namun kesamaannya terletak dalam penggunaan kekerasan baik terhadap pejabat resmi pemerintah yang dimusuhi atau kepada penduduk sipil dengan maksud menimbulkan kepanikan dan menarik perhatian publik terhadap tuntutan politik yang ingin diperjuangkan oleh kelompok yang melakukan aksi terorisme tersebut. Bagi kelompok teroris perjuangan dengan jalan damai atau dialog hanya membuang waktu dan energi dan karena itu aksi kekerasan merupakan satu-satunya jalan untuk mencapai tujuan politik. Selain perasaan frustasi dalam aksi terorisme ada juga unsur kebencian terhadap sasaran yang dituju apakah berupa public property dari negara yang dianggap sebagai musuh atau warga negara dari negara tersebut.

Untuk bisa mengidentifikasi siapa yang disebut terorisme dan apa yang mendasari lahirnya gerakan terorisme, salah satu yang menarik adalah seperti yang dijelaskan oleh Audrey Kurth Cronin (dalam Kiras, 2001:
480-481) yang membagi empat kategori jenis kelompok terorisme berdasarkan sumber motivasinya, yaitu: left-wing terrorist, right-wing terrorist, ethnonational/separatist terrorist, and religious or "sacred" terrorist. Namun Cronin juga menyadari bahwa pembagian tipe gerakan terorisme ini bukanlah secara tepat membagi kelompok-kelompok tersebut, karena masih banyak beberapa bentuk gerakan terorisme yang kemudian mengkombinasikan motivasi ideologis, seperti kebanyakan grup ethnonationalist yang memiliki religious characteristics walaupun biasanya tetap akan berpegangan pada satu ideologi atau dominasi pergerakan.

Ditambahkan pula oleh Kiras (2001: 481), kesulitan dalam menemukan definisi yang tepat mengenai teroris karena sulit menentukan tujuan kekerasan yang akan digunakan dan motivasi dibalik kegiatan terorisme sehingga sejak awal kemunculannya, pada akhirnya terorisme berbeda dari tindakan kriminal (criminal act). Berbagai perspektif yang muncul dari lahirnya gerakan terorisme secara global maupun yang lahir di kawasan Asia Tenggara menjadi modalitas atas terlaksananya kebijakan luar negeri Amerika Serikat dalam "war on terrorism", di mana dimensi terhadap kegiatan terorisme paska 11 September 2001 dianggap memiliki kesamaan ideologi dan moralitas yang mampu mengancam kedaulatan negara.

Walaupun sebelumnya regulasi terhadap pencegahan bahaya terorisme telah lahir melalui Konvensi Pencegahan dan Penghukuman Terorisme (Convention for The Prevention and Suppression of Terrorism) tahun 1937, terorisme diartikan sebagai crimes against state. Selanjutnya dalam European Convention on The Suppression of Terrorism (ECST) tahun 1977, pengertian terorisme berubah paradigmanya, yaitu dari semula sebagai crimes againts State (termasuk pembunuhan dan percobaan pembunuhan kepala negara atau anggota keluarganya), menjadi crimes againts humanity.

Setelah terjadi diaspora mengenai definisi terorisme, baik akibat dari meluasnya konflik yang terjadi maupun dari munculnya aktor-aktor baru, namun yang akhirnya kita 
pahami mengenai terorisme justru konstruksi pemahaman terorisme pasca 9/11 ini lebih dikenal sebagai trend baru sebagai postmodern terrorism atau new terrorism yang dalam pengertian berbeda diungkapkan memiliki motivasi oleh "promises of rewards in the afterlife" dan menggunakan alasan agama untuk membunuh sebanyak mungkin orangorang yang tidak memiliki keyakinan. Dalam beberapa peristiwa kasus pemboman diyakini di antara fenomena regional, kasus terorisme disponsori oleh negara (state-sponsored) seperti kasus militan Islam di Lebanon. Lanjut menurut Kiras, new terrorism dapat diartikan pula sebagai rasionalisasi global Jihad, yaitu sesuatu yang dipandang sebagai reaksi dari penindasan yang dirasakan umat muslim dan menurunnya nilai spiritual kaum barat (Kiras, 2001: 486).

Terjadinya kasus Bom Bali tahun 2002 yang telah menewaskan sekitar 200 orang diyakini bahwa penetrasi moralitas gerakan terorisme Al-Qaeda telah di pusatkan di kawasan ini sebagai bentuk militansi Islam seperti gerakan JI dan Gerakan Abu Sayyaf dan MILF yang mulai menunjukkan reaksi yang sama terhadap pemerintahan barat khususnya Amerika Serikat. Sedangkan Guraratna (2019) mengelompokkan lebih banyak kelompok ekstrimis yang dipandang lebih mendekati gerakan terorisme, di antaranya: MILF (Moro Islamic Liberation Front), Abu Sayyaf Group (ASG) di Philipina, Laskar Jundullah di Indonesia, Kumpulan Mujahidin Malaysia (KMM) di Malaysia, Jemmah Salafiyah (JS) di Thailand, Arakan Rohingya Nationalist Organization (ARNO) dan Rohingya Solidarity Organization (RSO) di Myanmar dan Bangladesh dan Jemaah Islamiyah (JI), organisasi Asia Tenggara yang hadir di Australia. Hampir semua kategori kelompok yang berbasis pada motivasi agama dan bersifat radikalisasi di kawasan Asia Tenggara menjadi satu definisi yang sangat sering dikaitkan dengan kelompok Al-Qaeda, di mana kelompok-kelompok di atas sudah cukup mewakili ancaman yang mampu membahayakan negara dan pemerintahan. Walau bila dicermati tidak seluruhnya dari daftar kelompok-kelompok di atas merupakan kelompok yang memiliki tujuan yang sama. Di antaranya ada beberapa ke- lompok separatisme yang memiliki motivasi religius. Pelaku terorisme di Asia Tenggara tidak hanya dilakukan oleh laki-laki dewasa, namun juga perempuan dan anak-anak yang seringkali merupakan keluarga seperti dalam peristiwa rangkaian pemboman di Surabaya pada bulan Mei 2018 (Nasir: 2019).

Berbeda dengan model gerakan terorisme internasional, gerakan terorisme di Asia Tenggara pada awalnya merupakan gerakan sentimen terhadap pemerintah nasional atas ketidakadilan dan alienasi yang diterimanya, dengan semangat etno-nationalism yang biasanya juga diiringi dengan membawa identitas religi yang dianutnya (Guraratna, 2019). Maka secara umum, gerakan terorisme di Asia Tenggara dapat dilihat sebagai gerakan yang lahir dari kelompok suku minoritas yang mempunyai preferensi "keyakinan" yang berbeda yang diperparah lagi mengalami masalah kesejahteraan dengan pemerintah nasional (Guraratna, 2019). Identitas agama yang digunakan adalah Agama Islam (Ramakrishna: 2005: 33-37), karena di beberapa daerah seperti Filipina, Aceh, dan Thailand, kelompok Islam menjadi kelompok minoritas atau setidaknya memiliki prinsip yang berbeda dari kelompok Islam lainnya. Namun pada intinya terbentuknya kelompok terorisme di Asia Tenggara disebabkan karena alasan policy yang tidak memihak mereka yang kemudiam berimbas pada rendahnya ekonomi. Dan hal inilah yang seringkali menjadi alasan terjadinya clash antara pemerintah dengan kelompok tersebut. Kelompok teroris Asia Tenggara pada mulanya murni lahir dari dari kelompok-kelompok etno-religious yang menginginkan separasi dari negara yang dinilai tidak dapat mengakomodir hak-hak mereka.

Bagaimanapun, ASEAN mempunyai kepentingan bersama untuk bekerjasama dalam memerangi kejahatan lintas negara, utamanya terorisme. Hal ini karena pada kenyataannya kejahatan lintas negara termasuk terorisme telah beroperasi secara transnasional. Sebenarnya ASEAN telah membuat berbagai kesepakatan dan fland of action yang cukup komprehensif dalam upaya penanggulangan bahaya terorisme. 
ASEAN dalam menanggapi isu terorisme yang berkembang pasca 9/11 telah mengambil langkah awal untuk menghadapi ancaman tersebut yaitu pada 5 November 2001 negara-negara anggota ASEAN menandatangani ASEAN Declaration on Joint Action to Counter Terrorism. Adapun poin-poin utama dalam deklarasi tersebut adalah sebagai berikut (Chow, 2005: 309):

1. Mengutuk peristiwa serangan 9/11 dan mempertimbangkan tindakan serangan tersebut juga bisa menimpa semua negara.

2. Menolak setiap upaya yang menghubungkan terorisme dengan agama atau ras manapun.

3. Meninjau dan memperkuat mekanisme nasional untuk memerangi terorisme.

4. Menyerukan untuk melakukan peningkatan pembagian informasi dan intelijen, serta kerjasama regional pada penegakan hukum.

5. Menyerukan kepada negara-negara ASEAN untuk menandatangani, meratifikasi atau mengakses semua konvensi anti terorisme yang relevan termasuk Konvensi Internasional dalam Pemberantasan dan Pendanaan Terorisme.

Sejak tahun 2002, ASEAN telah berkonsentrasi untuk melakukan pembentukan kerangka kerja hukum regional untuk menyelaraskan undang-undang anti terorisme nasional sebagai dasar untuk melakukan kerjasama antara negara. Sebagai contoh pada Mei 2002, pemerintah Indonesia, Filipina, dan Malaysia menandatangani Agreement on Exchange and Establishment of Communication Procedures. Perjanjian tersebut berisikan komitmen untuk berbagi daftar penumpang penerbangan, daftar hitam, database sidik jari yang terkomputerisasi, kemudian disertai dengan latihan gabungan antar negara dan pengawasan perbatasan dengan merancang sistem titik keluar dan masuk yang berstandar (Chow, 2005: 313). Perjanjian ini sangat relevan dengan penanggulangan terhadap terorisme karena peristiwa 9/11 yang terjadi di Amerika Serikat telah menggunakan pesawat terbang yang dibajak oleh para teroris dalam melancarkan aksinya dan juga perjanjian ini dapat membatasi dan mengawasi pergerakan orang-orang yang diduga terlibat dalam jaringan terorisme dalam hal mereka melakukan pergerakan antar negara.

Pada tahun 2003, Thailand, Kamboja dan Brunei ikut bergabung dalam mekanisme tersebut. Para pemimpin negara-negara ASEAN juga mendukung diadakannya Ad Hoc Experts Group Meeting dan sesi khusus dari Senior Officials Meeting on Tran snational Crime (SOMTC) dan ASEAN Ministerial Meeting on Transnational Crime (AMMTC) yang fokus dalam pembahasan terorisme dan menyerukan penandatanganan awal atau ratifikasi atau aksesi pada konvensi anti-terorisme, penguatan dan pertukaran informasi dan intelijen dan meningkatkan koordinasi dan kerjasama antara AMMTC dan entitas ASEAN lainnya dalam memerangi terorisme baik di tingkat regional maupun global.

Ancaman terorisme yang bersifat regional dianggap sebagai ancaman yang membutuhkan respon kolektif dari ASEAN untuk mengatasinya secara bersama-sama. Malaysia menjadi tuan rumah dalam ASEAN Ministrial Meeting on Terrorism pada Mei 2002. Komunike bersama bersama yang dihasilkan pada saat itu adalah menekankan persatatuan yang kohesif di antara negara anggota ASEAN agar secara efektif dapat memerangi terorisme di kawasan Asia Tenggara (Imperial, 2005: 17). Pada bulan Maret 2003, ASEAN Regional Forum (ARF) sebagai forum yang dibentuk ASEAN sebagai suatu wahana dialog dan konsultasi mengenai hal-hal yang terkait dengan politik dan keamanan kawasan serta untuk membahas dan menyamakan pandangan antara negara-negara peserta ARF untuk memperkecil ancaman terhadap stabilitas dan keamanan kawasan.

ARF menyelenggarakan rapat tahunan Inter-sessional Meeting on Counter Terrorism and Transnational Crime (ISM CT-TC) di Malaysia. Mitra ASEAN dalam melakukan dialog ini adalah Uni Eropa, AS, Jepang, China, Australia, dan Rusia. Pembahasan yang dilakukan adalah mengenai metode-metode khusus untuk meningkatkan pengawasan perbatasan dan standardisasi dokumen perjalanan dan penggunaan paspor biometrik. 
ASEAN juga telah membuka jalur komunikasi dengan berbagai kekuatan besar dunia, seperti yang yang ditunjukkan dalam forum ISM CT-TC di mana ASEAN telah menyepakati deklarasi bersama untuk memerangi terorisme dengan Uni Eropa (Januari 2003), India (Oktober 2003), Rusia (Juni 2004), Australia (Juni 2004) dan pertemuan tingkat menteri dalam isu kejahatan transnasional yang melibatkan China, Jepang dan Korea Selatan (AMMTC+3) untuk pertama kalinya pada Januari 2004 (Chow, 2005).

Pencapaian utama ASEAN dalam kampanye memberantas terorisme adalah dengan dideklarasikannya ASEAN Convention on Counter Terrorism pada tahun 2007. ACCT adalah konvensi yang mengikat negara-negara anggota ASEAN dalam komitmennya untuk melakukan perang melawan terorisme. Instrumen yang dibentuk dalam ACCT ini adalah penguatan kerjasama regional, misalnya dalam bantuan hukum timbal balik dalam masalah pidana dan adanya kemungkinan proses ekstradisi tersangka terorisme. ACCT merupakan salah satu dalam usaha peningkatan kerjasama keamanan dengan negara-negara yang tergabung dalam ASEAN untuk menanggulangi kejahatan terorisme. Konvensi ini telah ditandatangani oleh masing-masing negara anggota ASEAN pada KTT ASEAN ke-12 di Cebu Filipina tanggal 13 Januari 2007.

Tindakan terorisme merupakan kejahatan yang bersifat lintas batas negara dan telah mengakibatkan hilangnya banyak nyawa tanpa memandang korban, menimbulkan ketakutan pada masyarakat secara luas, hilangnya kemerdekaan, serta kerugian harta benda. Oleh karena itu perlu dilaksanakan berbagai langkah pemberantasan terorisme melalui kerjasama regional. Kerjasama keamanan dalam penanggulangan terorisme di ASEAN diperlukan untuk mewujudkan perdamaian dan stabilitas yang dinamis di kawasan Asia Tenggara. Dengan kestabilan tersebut akan menyokong terwujudnya komunitas masyarakat ASEAN pada tahun 2015.

Prinsip yang terkandung dalam ACCT antara lain memuat menghormati kedaulatan, dan kesetaraan, integritas wilayah dan identitas nasional, tidak campur tangan urusan dalam negeri, menghormati yurisdiksi kewilayahan, adanya bantuan hukum timbal balik, ekstradisi, serta mengedepankan penyelesaian perselisihan secara damai. Secara khusus dalam konvensi ini terdapat prinsip yang merupakan nilai tambah yang tidak dimiliki oleh konvensi pemberantasan terorisme yang lain, yaitu ketentuan mengenai program rehabilitasi atau deradikalisasi tersangka terorisme, perlakuan yang adil dan manusiawi, serta penghormatan terhadap hak asasi manusia dalam proses penanganannya (Chow, 2005).

Adanya berbagai kesepakatan dan komitmen yang ada di ASEAN menunjukkan bahwa upaya memerangi terorisme sesungguhnya tergantung pada kemauan politik negara-negara ASEAN sendiri dan diselesaikan dalam kerangka regional. Dalam kaitan ini diperlukan implementasi mekanisme regional secara nyata dari negara-negara ASEAN. ASEAN harus berdasar pada kerangka regional dalam melaksanakan berbagai mekanisme regional, meskipun identitas nasional tetap melekat.

Berbagai kesepakatan dan kerjasama yang telah dibuat ASEAN mencerminkan bahwa ASEAN hendak berupaya membangun mekanisme regional dalam penyelesaian konflik dan masalah terorisme secara regional. Namun demikian, kenyataan yang ada di lingkungan ASEAN belum mencerminkan itikad yang kuat dari negara-negara ASEAN untuk mematuhi kesepakatan-kesepakatan dan menggunakan mekanisme regional yang ada untuk penyelesaian masalah terorisme. Keberadaan ASC juga masih belum dijadikan tumpuan bagi para anggota ASEAN untuk menyelesaikan masalah-masalah keamanan ASEAN termasuk mengenai isu terorisme.

Penerapan mekanisme regional di ASEAN untuk memecahkan masalah terorisme di kawasan Asia Tenggara belum bisa dilaksanakan. Masing-masing negara ASEAN tampaknya masih mengandalkan pola yang sudah ada, yaitu melalui jalur bilateral, tidak melalui suatu mekanisme regional yang berlaku umum untuk keseluruhan anggota ASEAN. Dengan kata lain, respon ASEAN terhadap 
masalah aksi terorisme masih cenderung bersifat ad hoc.

Salah satu tantangan besar yang dihadapi ASEAN di bidang kerjasama counter terorism saat ini dan masa mendatang ádalah berkaitan dengan prinsip "ASEAN Way". Prinsip non-interference yang selama ini dianggap sacrosant, justru sering dianggap menjadi "hambatan" terhadap persoalan-persoalan penanggulangan terorisme yang senyatanya memerlukan "intervensi" dari sesama anggota. Digunakannya prinsip non interference demi menghormati kedaulatan dan keamanan nasional menjadikan sikap ASEAN kurang fleksibel dalam mengimplementasikan kerjasama counter terorism. Akibatnya, gerak ASEAN menjadi terbatas. Prinsip ini juga tidak memungkinkan ASEAN mengembangkan mekanisme diplomasi preventif yang bersifat aktif dan koersif.

Sikap tetap mempertahankan prinsip kedaulatan dan integritas nasional setiap negara anggota yang harus ditaati dalam counter terorism menghambat upaya penanganan masalah terorisme. Penyelesaian masalah yang banyak menimpa negara-negara ASEAN ini tentu akan sulit tanpa melibatkan negara-negara sekawasan. Dalam kenyataannya karena terorisme adalah masalah yang sangat spesifik, maka implementasi kerjasama counter terorism akan selalu bersinggungan dengan masalah kedaulatan negara lain. Apabila prinsip memegang teguh kedaulatan ini dipertahankan maka implementasi kesepakatan counter terorism menjadi sulit.

Kesulitan mencapai konsensus telah mendorong sementara negara anggota untuk mengaktifkan opsi-opsi yang berkerangka bilateral atau trilateral, sesuatu yang cenderung tidak produktif terhadap upaya pengembangan wawasan regional. Mekanisme konsensus menyebabkan dalam tingkat apapun penanganan masalah terorisme di ASEAN hanya akan bisa dilakukan apabila pihak-pihak yang bersangkutan menyetujui. Hal inilah yang kemudian menjadikan implementasi kesepakatan di ASEAN menjadi lambat dan bahkan tidak berjalan.

\section{Simpulan}

Salah satu tantangan besar yang dihadapi ASEAN di bidang kerjasama pemberantasan terorisme adalah dipegang teguhnya prinsip "ASEAN Way" dan prinsip non-interference karena faktor kedaulatan negara dan integritas nasional setiap negara anggota yang harus ditaati seringkali menghambat upaya penanganan masalah terorisme. Implementasi kerjasama pemberantasan terorisme akan selalu bersinggungan dengan masalah kedaulatan negara lain. Apabila prinsip memegang teguh kedaulatan ini dipertahankan maka implementasi kesepakatan pemberantasan terorisme menjadi sulit. Kesulitan mencapai konsensus tersebut telah mendorong sementara negara anggota untuk mengaktifkan opsi-opsi yang berkerangka bilateral atau trilateral, sesuatu yang cenderung tidak produktif terhadap upaya pengembangan wawasan regional.

Mekanisme konsensus menyebabkan dalam tingkat apapun penanganan masalah terorisme di ASEAN hanya akan bisa dilakukan apabila pihak-pihak yang bersangkutan menyetujui. Hal inilah yang kemudian menjadikan implementasi kesepakatan di ASEAN menjadi lambat dan bahkan tidak berjalan. Tidak ada lagi "masalah domestik" yang mutlak terpisah dari negara-negara yang lain di kawasan. Beberapa isu-isu domestik suatu negara dapat memiliki spill over effects (efek menyebar) kepada negara tetangganya. Oleh karena itu sangat tidak realistis dimasa sekarang bila negara-negara ASEAN mencoba memisahkan masalah dalam negerinya dengan negara tetangganya. Oleh karena itu penguatan kerjasama yang intensif dengan membuka ruang kedaulatan secara proporsional mutlak diperlukan dalam rangka mengatasi ancaman kawasan termasuk pemberantasan terorisme.

\section{Daftar Pustaka}

Bangun, B. H. (2017). Tantangan ASEAN dalam Melakukan Penanganan Pengungsi Rohingya. Padjadjaran Journal of Law, 4(3), 569-587.

Baylis, J., Owens, P., \& Smith, S. (Eds.). (2017). The globalization of world politics: an introduction to international relations. Oxford University Press.

Chow, J. T. (2005). ASEAN counterterrorism cooperation since 9/11. Asian Survey, 45(2), 302-321 
Cipto, B. (2007). Hubungan internasional di Asia Tenggara: teropong terhadap dinamika, realitas, dan masa depan. Pustaka Pelajar.

Held, D., McGrew, A., Goldblatt, D., \& Perraton, J. (2000). Global transformations: Politics, economics and culture. In Politics at the Edge (pp. 14-28). Palgrave Macmillan, London.

Hutchinson, T. C., \& Hutchinson, T. (2006). Researching and writing in law. Lawbook Company.

Imperial, N., Curley, M., \& Thomas, N. (2005). Securitisation and the Challenge of ASEAN Counterterrorism Cooperation. Centre of Asian Studies, University of Hong Kong.

Jackson, R. (2007). Sovereignty: The evolution of an idea. Polity.

Jasudasen, T. (2010). ASEAN's legal framework: lost its stripes or back with a roar?. Address by Singapore Ambassador to Malaysia before the ASEAN Law Association of Malaysia, Kuala Lumpur, 9.

Kivimäki, T. (2012). Southeast Asia and conflict prevention. Is ASEAN running out of steam?. The Pacific Review, 25(4), 403-427.

Luhulima, C. P. F. (2003). Pembrantasan Terorisme dan Kejahatan Transnasional dalam Pembangunan Keamanan Asia Tenggara. dalam Analisa CSIS. XXXII No, 1, 31-48.

Narine, S. (1999). ASEAN into the twenty-first century: Problems and prospects. The Pacific Review, 12(3), 357-380.

Nasir, A. (2019). Women in Terrorism: Evolution from Jemaah Islamiyah to Islamic State in Indonesia and Malaysia. Counter Terrorist Trends and Analyses, 11(2). Retrieved from https://www.jstor.org/stable/26627977
Ohmae, K. (1995). The end of the nation state: The rise of regional economies. Simon and Schuster.

Parashar, S. (Ed.). (2006). Terrorism in Southeast Asia: The Threat and Response: Report of an International Conference. Institute of Defence and Strategic Studies, Nanyang Technological University.

Ramakrishna, K. (2005). " The Southeast Asian Approach" to Counter-Terrorism: Learning from Indonesia and Malaysia. Journal of Conflict Studies, 25(1).

Smith, D. A., Solinger, D. J., \& Topik, S. (Eds.). (1999). States and sovereignty in the global economy. Psychology Press.

Sudirman, A. dan Sari, D.S. (2017). Membangun Keamanan Regional di ASEAN dalam Menanggulangi Ancaman Terorisme, Jurnal Wacana Politik, 2(1), 22-32.

Soesastro, H. (Ed.). (1995). ASEAN in a changed regional and international political economy. Centre for Strategic and International Studies.

Thomas, H. (2004). Cosmopolitan Sovereignty. Institute for Citizenship and Globalisation, Deakin University, Victoria.

Tjarsono, I. (2012). Isu Terorisme dan Beban Ancaman Keamanan Kawasan Asia Tenggara Pasca Runtuhnya WTC-AS. Jurnal Transnasional, 4(1). 1-10.

Vermonte, P. J. Problematika Peredaran Small Arms di Kawasan Asia Tenggara: Thailand, Filipina dan Indonesia. Analisis CSIS Tahun XXXII No, 1.

Weller, M., \& Wolff, S. (2005). Autonomy, Self Governance and Conflict Resolution: Innovative Approaches to Institutional Design in Divided Societies. Routledge. 